\title{
The Features of Floristic Composition and Community Structure of the Birch Forests in the Forest-to-Bog Ecotones in the South of the Vasyugan Plain
}

\author{
Nina V. Klimova*, Natalia A. Chernova, \\ Art'em N. Nikiforov and Anatoliy G. Dyukarev \\ Institute of Monitoring of Climatic and Ecological Systems SB RAS \\ Tomsk, Russian Federation
}

Received 04.07.2018, received in revised form 13.11.2018, accepted 25.01.2019

\begin{abstract}
The present study addresses the floristic composition and ecological and community structure of paludified birch forests (peat depth reaching $30 \mathrm{~cm}$ ) in the southern taiga. The growing conditions were evaluated based on the indicator values of plants and soil chemical properties. The study plots were located on transects directed from upland forests through peripheral wetland forests to bogs, which are situated in topographic lows, at the North-East edge of the Great Vasyugan mire. The sites of the forest-to-bog ecotone that are transformed to various degrees by the bog water regime are considered as successive stages of paludification. Because of the high carbonate content of the soil-forming rocks dominated by heavy clay particles and waterlogging by ground-mire waters, wet green forests without a developed moss cover form here on rich peat-humus soils at the initial stages of hydromorphic transformation of the plant community. This is in contrast to typical plant successions, which develop on carbonate-free sediments and whose development is associated with the effect of acid bog waters. Reed grass (Calamagrostis phragmitoides C. Hartman) dominates the ground vegetation, which also includes sedges (Carex canescens L., C. vaginata Tausch., C. disperma Dew.). The high contents of mineral nutrients in organics-accumulating dark humus soils determines the high floristic diversity of paludified birch forests, comparable with the diversity of upland communities. A significant part of the ground cover of these forests $(25 \%$ of the species composition, up to $50 \%$ of the projective cover) is represented by nutrient-demanding forest- and meadow-swamp plant species, which commonly occur in eutrophic boreal forested swamps of West Siberia with groundwater input. These species are absent in the mesotrophic paludified taiga forests. At a later stage of hydromorphic transformation, pine-birch shrub-moss forests form on peat-humus-
\end{abstract}

(C) Siberian Federal University. All rights reserved

This work is licensed under a Creative Commons Attribution-NonCommercial 4.0 International License (CC BY-NC 4.0).

* Corresponding author E-mail address: klimnin@sibmail.com

ORCID: 0000-0002-3253-1493 (Klimova N.); 0000-0003-1951-7192 (Chernova N.) 
gley and peat-gley soils. As the nutrient availability of soils declines, the number of plant species decreases, and plant species with lower nutrient requirements begin to predominate. This leads to the ecological restructuring of wet communities and makes them similar to paludified forests on carbonate-free sediments; peat accumulation begins with the deposition of mesotrophic peat. Thus, a more substantial change occurs in the ecological structure of plant communities on high-carbonate clays during their hydromorphic transformation compared to the typical mesotrophic paludification of dark-coniferous forests on loams.

Keywords: paludified forests, forest-to-bog ecotones, floristic diversity, ecological structure, community structure, indicator values of plants, phyto-indication, West Siberia.

Citation: Klimova N.V., Chernova N.A., Nikiforov A.N., Dyukarev A.G. The features of floristic composition and community structure of the birch forests in the forest-to-bog ecotones in the South of the Vasyugan plain. J. Sib. Fed. Univ. Biol., 2020, 13(1), 25-43. DOI: 10.17516/1997-1389-0314

\title{
Особенности флористического состава
}

\section{и ценотической структуры березовых лесов \\ в экотоне лес-болото на юге Васюганской равнины}

\author{
Н.В. Климова, Н.А. Чернова, \\ А.Н. Никифоров, А.Г. Дюкарев \\ Институт мониторинга климатических \\ и экологических систем СО РАН \\ Российская Федерации, Томск
}

\begin{abstract}
Аннотация. Приведены результаты изучения флористического состава, экологической и ценотической структуры, оценки лесорастительных условий в заболоченных березовых лесах (мощность торфа до 30 см) южной тайги. Исследования проведены на периферии небольших олиготрофных болот, приуроченных к понижениям рельефа в приболотном поясе на северовостоке Большого Васюганского болота. Здесь при высокой карбонатности почвообразующих пород тяжелого гранулометрического состава и подтоплении грунтово-болотными водами на начальных стадиях гидроморфной трансформации формируются богатые торфянистоперегнойные почвы с сырыми травяными лесами без развитого мохового покрова в отличие от типичных смен растительности, развивающихся под влиянием кислых болотных вод на бескарбонатных отложениях. Участки переходных полос между лесом и болотом, в разной степени трансформированные под влиянием водного режима торфяника, рассматриваются нами как последовательные стадии заболачивания. На ранней стадии развития процесса на органоаккумулятивных темно-гумусовых и перегнойно-темно-гумусовых почвах формируются заболоченные осиново-березовые леса с доминированием вейника Calamagrostis phragmitoides C. Hartman и участием осок (Carex canescens L., C. vaginata Tausch., C. disperma Dew.). Богатство


почв элементами минерального питания определяет их высокое флористическое разнообразие, сравнимое с разнообразием автоморфных сообществ. Значительную часть напочвенногопокрова этих лесов (25\% видового состава, до 50 \% проективного покрытия) составляют требовательные к трофности лесо- и лугово-болотные виды, характерные для эвтрофных лесных болот (согр) с питанием грунтовыми водами, отсутствующие при мезотрофном заболачивании таежных лесов. На более поздней стадии гидроморфной трансформации на торфяно-перегнойноглеевых и торфяно-глеевых почвах формируются сосново-березовые кустарничково-моховые леса. На фоне снижения трофности почв уменьшается число слагающих фитоценозы видов, среди них начинают преобладать менее требовательные к почвенному богатству. Это ведет к перестройке экологической структуры сообществ и сближает их с заболоченными лесами на бескарбонатных отложениях. Торфонакопление начинается с отложения переходного торфа. Таким образом, по сравнению с типичным мезотрофным заболачиванием темнохвойных таежных лесов на суглинках, на высококарбонатных глинах Васюганской равнины в процессе гидроморфной трансформации сообществ происходит более значительная перестройка их экологической структуры.

Ключевые слова: заболоченные леса, лесоболотные экотоны, флористическое разнообразие, экологическая структура, ценотическая структура, экологические шкалы, фитоиндикация, Западная Сибирь.

Цитирование: Климова, Н.В. Особенности флористического состава и ценотической структуры березовых лесов в экотоне лес-болото на юге Васюганской равнины / Н.В. Климова, Н.А. Чернова, А.Н. Никифоров, А.Г. Дюкарева // Журн. Сиб. федер. ун-та. Биология, 2020. 13(1). C. 25-43. DOI: 10.17516/1997-1389-0314

\section{Введение}

Заболачивание лесов - один из ключевых процессов на территории лесной зоны Западно-Сибирской равнины, где площади заболоченных лесов для среднетаежной подзоны составляют 7 \%, для южнотаежной - 4 \% (Глебов, Ускова, 1984), а локально, в частности на Васюганской равнине, увеличиваются до 13-30 \% (Васильев, Перегон, 2003).

Заболоченные леса являются неотъемлемой частью болотных массивов, оказывая большое влияние на их функционирование (Paradis et al., 2015) и на круговорот воды и углерода в целом (Ефремов и др., 2012). Важная особенность экосистем заболоченных лесов в том, что они переходные между лесом и болотом и обладают повышенной чувствительностью к изменениям окружающей сре- ды и климата (Ratcliffe et al., 2017), их состояние может служить надежным индикатором протекающих в природе процессов. Недостаточная изученность заболоченных лесов во многом обусловлена переходным (экотонным) характером этих экосистем и связанным с ним высоким разнообразием условий и факторов заболачивания (Васильев, Перегон, 2003; Пологова, Дюкарев, 2012 и др.). Высокая неоднородность и континуальность лесоболотных экотонов затрудняет их классификацию и последующую хозяйственную оценку заболоченных лесов (Ефремов и др., 2012; Bohn et al., 2015). Поэтому при их исследовании важно понимать и учитывать многофакторность системы и разнонаправленность процесса развития заболоченных лесных ландшафтов. 
На юге таежной зоны наибольшие площади заболоченных лесов сосредоточены на периферии крупных водораздельных болотных массивов, что связано с подтоплением окружающих лесных ландшафтов олиготрофными болотными водами (Лапшина и др., 2000). Как правило, в таких условиях формируются сообщества травяно-сфагновой группы типов (Кутенков, Кузнецов, 2013). Однако при наличии дополнительного подпитывания грунтовыми водами, карбонатности почвообразующих пород и богатства почв болотный процесс развивается по эвтрофному типу, малораспространенное явление, отмеченное Н.И. Пьявченко, в частности, на юге Западной Сибири (Пьявченко, 1985). Особенности формирования и строения заболоченных сообществ, связанные с богатством почвообразующих пород, выявлены и в лесоболотных экотонах южных окраин Большого Васюганского болота (Васильев, Перегон, 2003). Здесь, на богатых торфянисто-перегнойных почвах, что связано с высокой карбонатностью почвообразующих пород, слагающих Васюганскую равнину (Dyukarev, Pologova, 2011; Пологова, Дюкарев, 2012), на переходе от леса к болоту формируются сырые травяные леса со слабо развитым моховым покровом (Храмов, Валуцкий, 1977; Горожанкина, Константинов, 1978; Лапшина, 2010). В то же время на северных окраинах болота, сложенных бескарбонатными отложениями, заболачивание развивается под влиянием кислых болотных вод с типичной для Западной Сибири сменой растительности (Горожанкина, Константинов, 1976; Dyukarev, Pologova, 2011). Для выявления особенностей заболачивания лесов на карбонатных почвообразующих породах мы изучали их флористический состав, экологическую и ценотическую структуру, а также провели оценку лесорастительных условий в переходных лесоболотных полосах северо-восточной периферии Большого Васюганского болота. Поскольку коренные леса после пожаров начала прошлого века и современных рубок здесь до сих пор не восстановились (Данченко, Бех, 2010), исследования осуществлены в заболоченных березовых лесах.

\section{Объекты и методы}

Район исследований - юго-восточная часть Васюганской аккумулятивной равнины в левобережье Оби (бассейн р. Чая) (рис. 1), входящая в южнотаежную подзону лесной зоны Западной Сибири (Природно-ресурсное ..., 1997). Климат холодный, континентальный. По данным ближайшей метеостанции Бакчар, среднегодовая температура воздуха минус $0,3{ }^{\circ} \mathrm{C}$, средняя температура самого холодного месяца - января минус $19,3{ }^{\circ} \mathrm{C}$, самого теплого месяца - июля $-18,1{ }^{\circ} \mathrm{C}^{1}$. Длительность периода с температурами выше $10{ }^{\circ} \mathrm{C}$ 100-105 дней, сумма температур $-1573{ }^{\circ} \mathrm{C}$. Среднегодовое количество осадков - 483 мм, с максимумом в летний период. Равнина сложена карбонатными глинами и тяжелыми суглинками (Природно-ресурсное ..., 1997). В условиях плоского рельефа, превышения количества осадков над испарением, низкой водопроницаемости почвообразующих пород, слабой дренирующей способности рек почвенно-грунтовые и грунтовые воды повсеместно встречаются на глубине не более 3 м и постоянно подпитываются водами, стекающими с обширных водораздельных болот (Ружанский, 1972). Это благоприятствует развитию болотообразовательного процесса и заболачиванию лесов (Караваева, 1982; Пьявченко, 1985; Лапшина и др., 2000). Минерализация грунтовых вод, относящихся к гидрокарбонатно-кальциевому типу, не пре-

Климат России: научно-прикладной справочник [электронный ресурc]. - URL: http://aisori.meteo.ru/ ClspR, дата обращения 27.04.18. 


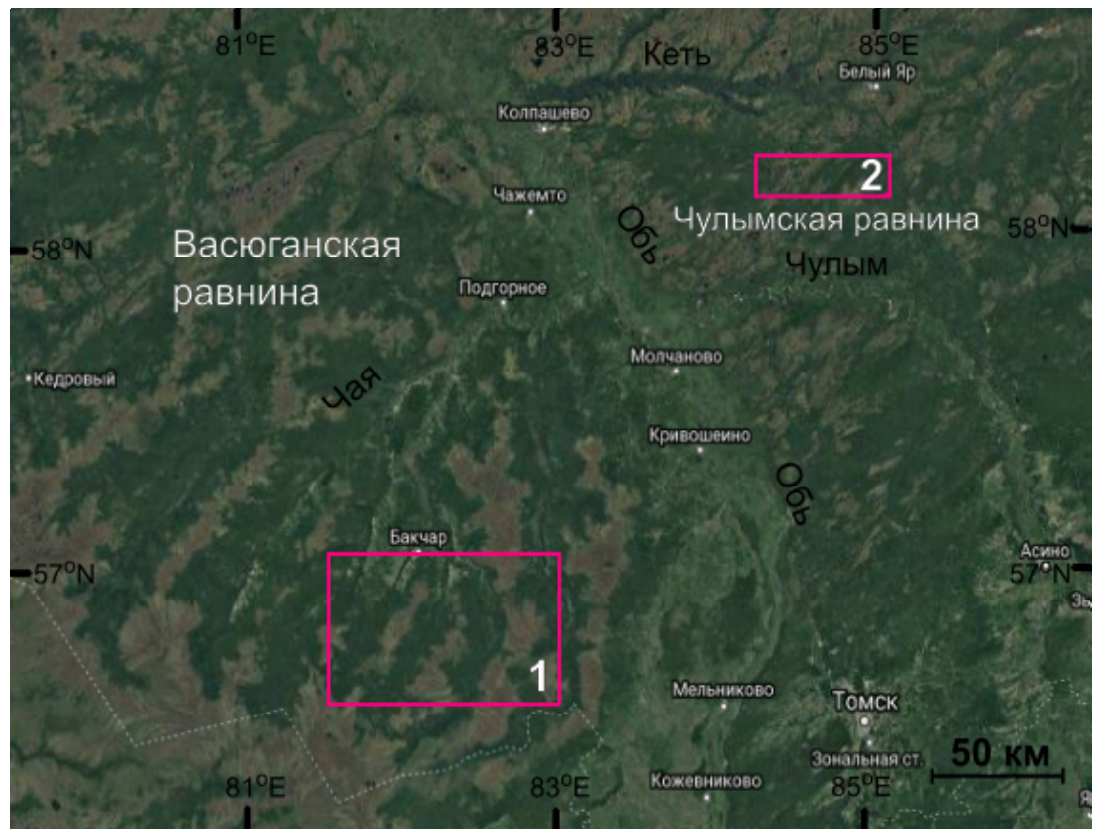

Рис. 1. Район исследований: 1 - Васюганская равнина; 2 - Чулымская равнина. Использован фрагмент космоснимка с сайта https:/www.google.com/maps

Fig. 1. Study area: 1 - Vasyugan plain; 2 - Chulym plain. A satellite imagery fragment was used from https:// www.google.com/maps

вышает 1 г/л (Ружанский, 1972). В почвенном покрове при высоком богатстве почвообразующих пород и нарастающем увлажнении формируется ряд органо-аккумулятивных почв, включающий дерновые оподзоленные, дерновые, темно-гумусовые, перегнойнотемно-гумусовые органо-аккумулятивные, торфяно-перегнойные остаточно гумусовые и торфяные почвы.

В автоморфных положениях наибольшие площади в настоящее время занимают осиново-березовые разнотравно-осочковые леса (Храмов, Валуцкий, 1977), формирующиеся на органо-аккумулятивных дерновых оподзоленных и дерновых остаточногумусовых почвах (Dyukarev, Pologova, 2011). «Зональные» темнохвойные леса в начале прошлого века выгорели на значительной части территории (Данченко, Бех, 2010). Восстановление их на богатых почвах при постоянном достаточном увлажнении под пологом лиственных лесов с густым травяным покровом идет очень медленно: в приболотном поясе отмечен редкий подрост ели и кедра, а на наиболее дренированных участках - слабое возобновление пихты. Вероятно, эти леса следует относить к длительно-производным или даже условно-коренным и связывать это с эколого-историческими причинами. Подобные явления уже отмечались на юге лесной зоны (Лащинский, 2009). Болота на выбранной территории разнообразны (Храмов, Валуцкий, 1977; Лапшина, 2010). Нами исследованы периферические участки небольших верховых болот (всего 11), представленных сосновыми кустарничково-сфагновыми сообществами и приуроченных к локальным понижениям в приболотном поясе на северо-востоке Большого Васюганского болота. На трансектах, заложенных от дренированных участков к центру понижений с болотом, в переходной лесоболотной полосе 


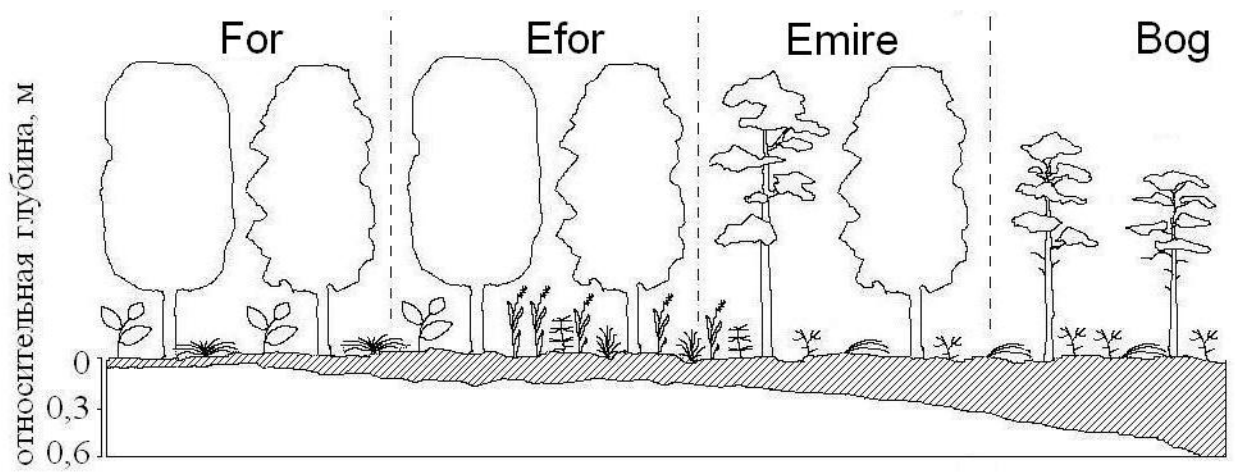

Рис. 2. Схема пространственной структуры лесоболотного экотона. For - автоморфные леса (осиновоберезовые разнотравно-осочковые), Efor-лесная часть экотона (осиново-березовые осоково-вейниковые), Emire - болотная часть экотона (сосново-березовые кустарничково-моховые), Bog - верховое болото (сосново-кустарничково-сфагновое). Штриховкой показана мощность подстилки, торфа

Fig. 2. Scheme of the spatial structure of the forest-to-bog ecotone. For - upland forests (aspen-birch mixed herbaceous communities), Efor - forest part of ecotone (aspen-birch sedge-reed grass communities), Emire - mire part of ecotone (pine-birch shrub-moss communities), Bog - bog (pine-shrub-sphagnum moss communities). Hatching shows the thickness of the litter and peat

(рис. 2) выделены: 1) лесная часть экотона с осиново-березовыми осоково-вейниковыми лесами на периодически увлажняемых органо-аккумулятивных темно-гумусовых и перегнойно-темно-гумусовых почвах (forest part of ecotone, Efor); 2) болотная часть экотона с сосново-березовыми кустарничковомоховыми лесами на переувлажненных торфяно-перегнойно-глеевых и торфяноглеевых почвах (mire part of ecotone, Emire) (Пологова, Дюкарев, 2012). С точки зрения функционирования лесоболотного экотона как ландшафтной единицы (Пологова, 2001) мы рассматриваем выделенные в нем части как стадии, последовательно сменяющие друг друга при развитии заболачивания под влиянием водного режима болота. По классификации Н.И. Пьявченко (1985), фитоценозы и лесной и болотной частей экотона относятся к категории заболоченных лесов с мощностью торфа до 30 см. При этом осиново-березовые осоково-вейниковые леса занимают влажные и слабо заболоченные биотопы, а сосновоберезовые кустарничково-моховые - умеренно и сильно заболоченные.
Флористическое разнообразие растительных сообществ анализировали на основе геоботанических описаний. Всего выполнено 21 описание в автоморфных березовых травяных лесах (For), 25 - в осиново-березовых осоково-вейниковых (Efor), 23 - в сосновоберезовых кустарничково-моховых (Emire) и 23 - в сосновых кустарничково-сфагновых болотных сообществах (Bog). Для сравнения мы использовали также описания заболоченных темнохвойных лесов на суглинках (Пологова и др., 2013), слагающих ряд мезотрофного заболачивания (рис. 1). Альфа- и гамма-разнообразие оценивали через видовое богатство (общее число видов в группе геоботанических описаний, относящихся к одному типу сообщества) и видовую насыщенность (среднее число видов на площадке 25 х 25 м), рассчитанные в программе EstimateS (Colwell, 2013) по данным присутствия/отсутствия видов. Получаемая видовая аккумулятивная кривая позволяет корректно сравнивать сообщества по выборкам разного объема (Смирнов и др., 2014). Бета-разнообразие оценивали с помощью коэффициентов сходства Жакка- 
pa $\left(\mathrm{K}_{\mathrm{J}}\right)$, принимающих значения от 0 до 1 , в соответствии с рекомендациями (Magurran, 2004). Для анализа ценотической структуры сообществ использовали ценотические и экологические группы видов, предложенные Е.Д. Лапшиной (2003).

Условия местообитаний оценивали фитоиндикационным методом с применением экологических шкал (Методические ..., 1978) на основе полных флористических списков. Расчеты статусов фитоценозов по основным факторам - увлажнению и богатству почв - сделаны согласно рекомендациям А.А. Зверева: с учетом индикационной значимости видов, а также их обилия (Зверев, Бабешина, 2009). Кроме того, использован ряд показателей химических свойств почв (содержание гумуса, состав почвенного поглощающего комплекса, pH водный, содержание карбонатов), определенных общепринятыми в почвоведении методами.

\section{Результаты и обсуждение}

Анализ флористического состава, экологической и ценотической структуры заболоченных лесов, объединяющих сообщества разных стадий гидроморфной трансформа- ции в переходных лесоболотных полосах на юге Васюганской равнины, позволил выявить ряд особенностей, отличающих их как от лесов, составляющих мезотрофную серию заболачивания, так и от пойменных сообществ эвтрофной серии. Данные по флористическому составу исследованных лесов сведены в таблицу (табл. 1), приведены виды со встречаемостью 40 \% и более в каком-либо из фитоценозов. Названия сосудистых растений даны по: (Конспект ..., 2005), мохообразных (Игнатов, Афонина, 1992).

В осиново-березовых осокововейниковых лесах, находящихся на ранней стадии гидроморфной трансформации (Efor), микрорельеф кочково-западинный, образованный приствольными повышениями 20-30 см высотой и до 1,5-2 м в диаметре, замшелыми пнями, валежинами и мелкими вейниковыми и осоковыми кочками (10-20 см высотой), изредка встречаются более крупные (до 50 см) кочки Carex cespitosa L. Вода стоит на поверхности микропонижений, мертвопокровных или с разреженным напочвенным покровом. Древостой, как и в лесах автоморфных положений (For), из березы и осины, высотой (18)20-22 м, сомкнутость крон 0,5-0,6.

Таблица 1. Растительные сообщества лесоболотных экотонов

Table 1. Plant communities of forest-to-bog ecotones

\begin{tabular}{|c|c|c|c|c|c|c|}
\hline \multicolumn{3}{|c|}{$\begin{array}{c}\text { Фитоценоз } \\
\text { Число описаний }\end{array}$} & $\begin{array}{c}\text { For } \\
21\end{array}$ & $\begin{array}{c}\text { Efor } \\
25\end{array}$ & $\begin{array}{c}\text { Emire } \\
23\end{array}$ & $\begin{array}{c}\text { Bog } \\
23\end{array}$ \\
\hline Вид & ярус & ЦГ & & & & \\
\hline 1 & 2 & 3 & 4 & 5 & 6 & 7 \\
\hline Pinus sibirica Du Tour & a1 & & II & I & III $^{1}$ & II \\
\hline Betula alba L. & al & & $\mathrm{V}^{2}$ & $\mathrm{~V}^{3}$ & $\mathrm{~V}^{3}$ & $\mathrm{III}^{+}$ \\
\hline Populus tremula L. & al & & $\mathrm{V}^{3}$ & $\mathrm{IV}^{2}$ & + & \\
\hline Pinus sylvestris L. & al & & I & III $^{1}$ & $\mathrm{~V}^{2}$ & $\mathrm{~V}^{2}$ \\
\hline Pinus sibirica Du Tour & a3 & & II & $\mathrm{IV}^{+}$ & $\mathrm{V}^{1}$ & $\mathrm{~V}^{+}$ \\
\hline Betula alba L. & a3 & & $\mathrm{IV}^{+}$ & $\mathrm{V}^{1}$ & $\mathrm{~V}^{1}$ & $\mathrm{~V}^{1}$ \\
\hline Populus tremula L. & a3 & & $\mathrm{V}^{1}$ & $\mathrm{III}^{+}$ & II & \\
\hline
\end{tabular}


Продолжение табл. 1

Continued Table 1

\begin{tabular}{|c|c|c|c|c|c|c|}
\hline 1 & 2 & 3 & 4 & 5 & 6 & 7 \\
\hline Pinus sylvestris L. & a3 & & + & $\mathrm{IV}^{+}$ & $\mathrm{V}^{1}$ & $\mathrm{~V}^{1}$ \\
\hline Padus avium Miller & $\mathrm{b}$ & fl-for & $\mathrm{IV}^{1}$ & I & $\mathrm{r}$ & \\
\hline Rubus idaeus L. & $\mathrm{b}$ & for & $\mathrm{IV}^{1}$ & II & $\mathrm{r}$ & \\
\hline Caragana arborescens Lam. & $\mathrm{b}$ & for & $\mathrm{IV}^{2}$ & $\mathrm{III}^{+}$ & $\mathrm{r}$ & \\
\hline Rosa acicularis Lindley & $\mathrm{b}$ & for & $\mathrm{IV}^{1}$ & $\mathrm{III}^{+}$ & $\mathrm{r}$ & \\
\hline Sorbus sibirica Hedl. & $\mathrm{b}$ & for & $\mathrm{IV}^{+}$ & $\mathrm{IV}^{+}$ & I & \\
\hline Salix caprea L. & $\mathrm{b}$ & for & II & III $^{1}$ & & $\mathrm{r}$ \\
\hline Ribes nigrum L. & $\mathrm{b}$ & fl-for & $\mathrm{III}^{+}$ & $\mathrm{III}^{+}$ & $\mathrm{r}$ & \\
\hline Carex macroura Meinsh. & $\mathrm{c}$ & for & $\mathrm{IV}^{2}$ & & & \\
\hline Aegopodium podagraria $\mathrm{L}$. & $\mathrm{c}$ & for & $\mathrm{IV}^{2}$ & I & & \\
\hline Calamagrostis obtusata Trin. & $\mathrm{c}$ & for & $\mathrm{V}^{2}$ & I & & \\
\hline Equisetum pratense Ehrh. & $\mathrm{c}$ & for & $\mathrm{V}^{1}$ & II & & \\
\hline Rubus saxatilis L. & $\mathrm{c}$ & for & $\mathrm{V}^{1}$ & II & & \\
\hline Cirsium heterophyllum (L.) Hill & $\mathrm{c}$ & for & III $^{1}$ & + & & \\
\hline Pulmonaria mollis Wulfen ex Hornem. & $\mathrm{c}$ & for & $\mathrm{IV}^{1}$ & I & & \\
\hline Stellaria bungeana Fenzl. & $\mathrm{c}$ & for & $\mathrm{IV}^{1}$ & I & & \\
\hline Paris quadrifolia $\mathrm{L}$. & $\mathrm{c}$ & for & $\mathrm{IV}^{+}$ & I & & \\
\hline Vicia sylvatica L. & $\mathrm{c}$ & for & $\mathrm{IV}^{+}$ & I & & \\
\hline Galium boreale L. & $\mathrm{c}$ & mead & $\mathrm{IV}^{+}$ & I & & \\
\hline Lathyrus pratensis L. & $\mathrm{c}$ & mead & $\mathrm{III}^{+}$ & I & & \\
\hline Aconitum septentrionale Koelle & $\mathrm{c}$ & for & $\mathrm{IV}^{+}$ & $\mathrm{r}$ & & \\
\hline Crepis sibirica $\mathrm{L}$. & $\mathrm{c}$ & for & III $^{1}$ & & & \\
\hline Milium effusum L. & $\mathrm{c}$ & for & III $^{1}$ & & & \\
\hline Pleurospermum uralense Hoffm. & $\mathrm{c}$ & for & $\mathrm{III}^{+}$ & & & \\
\hline Melica nutans L. & c & for & $\mathrm{III}^{+}$ & $\mathrm{r}$ & & \\
\hline Thalictrum minus $\mathrm{L}$. & $\mathrm{c}$ & for & III $^{1}$ & $\mathrm{r}$ & & \\
\hline Viola selkirkii Pursh ex Goldie & $\mathrm{c}$ & for & $\mathrm{IV}^{+}$ & I & & \\
\hline Vicia sepium $\mathrm{L}$. & $\mathrm{c}$ & for & $\mathrm{IV}^{+}$ & $\mathrm{III}^{+}$ & $\mathrm{r}$ & \\
\hline Angelica sylvestris L. & $\mathrm{c}$ & for & $\mathrm{IV}^{+}$ & II & $\mathrm{r}$ & \\
\hline Athyrium filix-femina (L.) Roth & $\mathrm{c}$ & for & $\mathrm{IV}^{1}$ & II & $\mathrm{r}$ & \\
\hline Cacalia hastata L. & $\mathrm{c}$ & for & $\mathrm{IV}^{+}$ & II & $\mathrm{r}$ & \\
\hline Solidago virgaurea $\mathrm{L}$. & $\mathrm{c}$ & for & $\mathrm{III}^{+}$ & $\mathrm{III}^{+}$ & + & \\
\hline Oxalis acetosella $\mathrm{L}$. & $\mathrm{c}$ & for & III $^{1}$ & I & $\mathrm{r}$ & \\
\hline Gymnocarpium dryopteris (L.) Newm. & $\mathrm{c}$ & for & III $^{1}$ & $\mathrm{IV}^{+}$ & & \\
\hline Maianthemum bifolium (L.) F.W. Schmidt & $\mathrm{c}$ & for & $\mathrm{IV}^{+}$ & $\mathrm{V}^{1}$ & II & \\
\hline Rubus arcticus $\mathrm{L}$. & $\mathrm{c}$ & for & $\mathrm{IV}^{+}$ & $\mathrm{V}^{1}$ & II & \\
\hline Trientalis europaea L. & $\mathrm{c}$ & for & $\mathrm{IV}^{+}$ & $\mathrm{V}^{+}$ & $\mathrm{III}^{+}$ & \\
\hline Dryopteris carthusiana (Vill.) H.P. Fuchs & $\mathrm{c}$ & for & II & $\mathrm{III}^{+}$ & II & \\
\hline Equisetum sylvaticum L. & $\mathrm{c}$ & for & $\mathrm{IV}^{1}$ & $\mathrm{~V}^{2}$ & $\mathrm{~V}^{1}$ & II \\
\hline Filipendula ulmaria (L.) Maxim. & $\mathrm{c}$ & mead-sw & $\mathrm{IV}^{1}$ & $\mathrm{III}^{1}$ & & \\
\hline
\end{tabular}


Продолжение табл. 1

Continued Table 1

\begin{tabular}{|c|c|c|c|c|c|c|}
\hline 1 & 2 & 3 & 4 & 5 & 6 & 7 \\
\hline Calamagrostis phragmitoides C. Hartman & $\mathrm{c}$ & mead-sw & II & $\mathrm{V}^{2}$ & II & \\
\hline Carex vaginata Tausch. & $\mathrm{c}$ & for-sw & II & $\mathrm{IV}^{1}$ & + & \\
\hline Carex canescens $\mathrm{L}$. & $\mathrm{c}$ & for-sw & & III $^{1}$ & $\mathrm{r}$ & \\
\hline Carex disperma Dew. & $\mathrm{c}$ & for-sw & I & $\mathrm{III}^{+}$ & $\mathrm{r}$ & \\
\hline Ranunculus repens $\mathrm{L}$. & $\mathrm{c}$ & mead-sw & II & $\mathrm{III}^{+}$ & $\mathrm{r}$ & \\
\hline Epilobium palustre L. & $\mathrm{c}$ & mire & + & $\mathrm{III}^{+}$ & & \\
\hline Naumburgia thyrsiflora (L.) Reichenb. & $\mathrm{c}$ & mire & $\mathrm{r}$ & $\mathrm{III}^{+}$ & $\mathrm{r}$ & \\
\hline Equisetum palustre L. & $\mathrm{c}$ & mire & I & $\mathrm{III}^{+}$ & I & \\
\hline Vaccinium vitis-idaea $\mathrm{L}$. & $\mathrm{c}$ & for & II & $\mathrm{IV}^{1}$ & $\mathrm{~V}^{1}$ & $\mathrm{~V}^{1}$ \\
\hline Vaccinium myrtillus L. & $\mathrm{c}$ & for & + & II & III $^{1}$ & III $^{1}$ \\
\hline Ledum palustre $\mathrm{L}$. & $\mathrm{c}$ & bog & I & $\mathrm{IV}^{+}$ & $\mathrm{V}^{2}$ & $\mathrm{~V}^{2}$ \\
\hline Carex globularis L. & $\mathrm{c}$ & bog & I & $\mathrm{V}^{2}$ & $\mathrm{~V}^{2}$ & $\mathrm{~V}^{1}$ \\
\hline Chamaedaphne calyculata (L.) Moench & $\mathrm{c}$ & bog & & II & $\mathrm{V}^{1}$ & $\mathrm{~V}^{2}$ \\
\hline Rubus chamaemorus L. & $\mathrm{c}$ & bog & & + & $\mathrm{III}^{+}$ & $\mathrm{V}^{+}$ \\
\hline Oxycoccus palustris Pers. & $\mathrm{c}$ & bog & & & + & $\mathrm{III}^{+}$ \\
\hline Pleurozium schreberi (Brid.) Mitt. & $d$ & for & III $^{1}$ & $\mathrm{~V}^{1}$ & $\mathrm{~V}^{1}$ & $\mathrm{~V}^{2}$ \\
\hline Dicranum polysetum Sw. & d & for & II & II & $\mathrm{IV}^{+}$ & $\mathrm{IV}^{+}$ \\
\hline Ptilium crista-castrensis (Hedw.) De Not. & d & for & $\mathrm{r}$ & $\mathrm{III}^{+}$ & II & $\mathrm{III}^{+}$ \\
\hline Hylocomium splendens (Hedw.) Schimp. in B.S.G. & $\mathrm{d}$ & for & II & $\mathrm{III}^{+}$ & II & $\mathrm{III}^{+}$ \\
\hline Brachythecium oedipodium (Mitt.) Jaeg. & d & for & $\mathrm{III}^{+}$ & $\mathrm{III}^{+}$ & $\mathrm{III}^{+}$ & I \\
\hline Plagiomnium cuspidatum (Hedw.) T.Kop. & d & for & $\mathrm{III}^{+}$ & $\mathrm{III}^{+}$ & $\mathrm{r}$ & \\
\hline $\begin{array}{l}\text { Brachythecium salebrosum (Web. et Mohr) Schimp. } \\
\text { in B.S.G. }\end{array}$ & d & for & + & $\mathrm{III}^{+}$ & I & \\
\hline Brachythecium sp. & d & for & $\mathrm{III}^{+}$ & II & I & $\mathrm{III}^{+}$ \\
\hline Plagiomnium ellipticum (Brid.) T.Kop. & d & for-sw & III $^{1}$ & $\mathrm{IV}^{1}$ & $\mathrm{r}$ & $\mathrm{r}$ \\
\hline Climacium dendroides (Hedw.) Web. et Mohr. & $\mathrm{d}$ & for-sw & II & III $^{1}$ & + & \\
\hline Helodium blandowii (Web. et Mohr) Warnst. & d & for-sw & & $\mathrm{IV}^{+}$ & I & \\
\hline Calliergon cordifolium (Hedw.) Kindb. & $\mathrm{d}$ & for-sw & $\mathrm{r}$ & III $^{1}$ & II & \\
\hline Sphagnum squarrosum Crome & d & for-sw & & III $^{1}$ & II & \\
\hline Sphagnum centrale C.Jens ex H.Arnell et C.Jens. & d & mire & & $\mathrm{III}^{+}$ & II & $\mathrm{r}$ \\
\hline Aulacomnium palustre (Hedw.) Schwaegr. & d & mire & II & $\mathrm{IV}^{+}$ & $\mathrm{V}^{+}$ & $\mathrm{V}^{+}$ \\
\hline Sphagnum russowii Warnst. & $\mathrm{d}$ & bog & & II & III $^{1}$ & $\mathrm{~V}^{1}$ \\
\hline Polytrichum strictum Brid. & d & bog & $\mathrm{r}$ & II & $\mathrm{IV}^{+}$ & $\mathrm{IV}^{+}$ \\
\hline Sphagnum angustifolium (Russ. ex Russ.) C.Jens & $\mathrm{d}$ & bog & & $\mathrm{III}^{+}$ & $\mathrm{V}^{2}$ & $\mathrm{~V}^{3}$ \\
\hline Sphagnum magellanicum Brid. & d & bog & & II & IV $^{1}$ & $\mathrm{~V}^{2}$ \\
\hline Sphagnum fuscum (Schimp.) Klinggr. & $\mathrm{d}$ & bog & & & I & III $^{1}$ \\
\hline
\end{tabular}

Примечание. Обозначения фитоценозов как на рис. 2. Ярус: a1 - древесный, а3 - подрост, b - подлесок, с травяно-кустарничковый, d - мохово-лишайниковый. ЦГ - ценотическая группа (приуроченность к фитоценозу): mead - луговые, for - лесные, fl-for - пойменно-лесные, for-sw - лесоболотные, mead-sw - лугово-болотные, mire болотные (мезотрофы), bog - болотные (мезоолиготрофы и олиготрофы). Римскими цифрами обозначены классы встречаемости, \%: V - от 81 до 100; IV - от 61 до 80; III - от 41 до 60; II - от 21 до 40; I - от 10 до 20; + - до 10; r единично. Надстрочные индексы показывают обилие в баллах: 3 - от 26 до 50 \% проективного покрытия; 2 - от 6 до $25 \%$; 1 - от 1 до $5 \%$; +- менее $1 \%$. Пустые ячейки означают отсутствие вида. 
Подлесок редкий (1-5(10) \%). Травяной покров хорошо развит (45-70(80) \%), но в отличие от автоморфных березняков, где доминируют лесные мезофиты, наибольшее проективное покрытие у более влаголюбивых видов из разных ценотических групп (лугово-болотного Calamagrostis phragmitoides (15-40(50) \%), лесного Equisetum sylvaticum (3-15(25) \%) и болотного Carex globularis (1-15(20) \%)). Моховой покров (3-30 \%) представлен небольшими дернинами лесоболотных мхов из родов Plagiomnium, Climacium, Calliergon, Sphagnum. На микроповышениях в небольшом обилии произрастают лесные кустарнички, мелкотравье, лесные зеленые мхи.

В сосново-березовых кустарничковомоховых фитоценозах (Emire), соответствующих следующей стадии гидроморфной трансформации, микрорельеф хорошо выраженный, образованный приствольными повышениями, замшелыми пнями и валежинами, иногда кочками пушицы. Относительный перепад высот варьирует в широких пределах - 10-50(70) см. Вода стоит на поверхности микропонижений, большей частью мертвопокровных. Древостой наряду с березой слагает сосна, его высота 16-20 м, сомкнутость крон $0,5-0,6$. По сравнению с болотом сосна лучше развита (лесной, а не болотной формы). Напочвенный покров из-за переменного в течение вегетационного сезона увлажнения разреженный. Основу его составляют кустарнички (15-40(50) \%), осока шароплодная Carex globularis (5-15(25) \%) и мхи (5-60(80) \%). Последние представлены небольшими дернинами лесоболотных видов, а на границе с болотом - мелкими и крупными (до 1-1,5 м) дернинами-пятнами болотных сфагнов, на микроповышениях встречаются лесные зеленые мхи.

По сравнению с заболоченными кустарничково -осоково-зеленомошно- сфагновыми лесами мезотрофной серии заболачивания (Пологова и др., 2013) березняки осоково-вейниковые отличаются лучшим развитием травяного покрова и очень слабым развитием мхов. В сосново-березовых кустарничково-моховых сообществах, как и в кустарничково-осоково-сфагновых лесах мезотрофной серии, моховой покров развит лучше и представлен лесоболотными и болотными видами.

Видовое богатство березняков осокововейниковых (Efor) сопоставимо (различия не значимы при $\mathrm{p}>0,05)$ с богатством автоморфных сообществ (For), где выявлено максимальное число видов (рис. 3). В сосново-березовых кустарничково-моховых фитоценозах (Emire) видовое богатство меньше. В болотных фитоценозах (рослых рямах) (Bog) обнаружено минимальное число видов. Сходные результаты получены при сопоставлении видовой насыщенности (25х25 м) фитоценозов (рис. 3, для одного описания). По числу видов заболоченные березняки Васюганской равнины богаче, чем леса соответствующих стадий мезотрофной серии заболачивания (рис. 3). Меньшее число видов для автоморфных и заболоченных мезотрофных лесов отмечается и в более ранних публикациях по южнотаежной подзоне Западной Сибири (128 и 137 видов - в хорошо дренированных травяных и мелкотравнозеленомошных темнохвойных лесах, 32 и 33 описания, соответственно (Лащинский, Королюк, 2015); 122 вида - в хорошо дренированных травяных пихтовых лесах, 103 вида - в заболоченных сфагновых кедровниках (Горожанкина, Константинов, 1978)). С другой стороны, исследованные нами леса уступают по числу видов пойменным эвтрофным лесным болотам (335 видов - в темнохвойно-березовых сограх, 43 описания (Лапшина, 2010). 


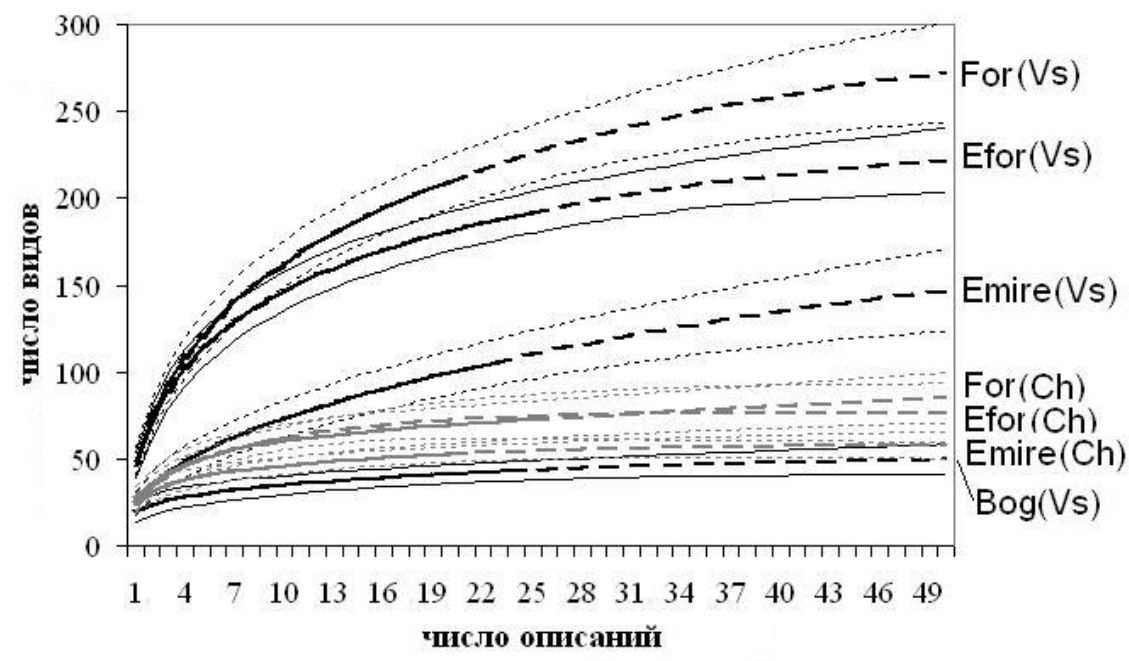

Рис. 3. Видовые аккумулятивные кривые фитоценозов лесоболотных экотонов. Обозначения фитоценозов как на рис. 2 (Vs - Васюганская равнина, $\mathrm{Ch}$ - Чулымская равнина). Сплошная линия - интерполяционная часть, пунктирная - экстраполяционная часть кривой, тонкие линии ограничивают области 95 \%-ных доверительных интервалов

Fig. 3. Species accumulation curves for the plant communities of forest-to-bog ecotones. Notations as in Fig. 2 (Vs - Vasyugan plain, $\mathrm{Ch}$-Chulym plain). Thick solid line is interpolated part and thick dashed line is extrapolated part of the curves. Thin lines limit the confidence area (95\%)

Таблица 2. Сравнение фитоценозов лесоболотных экотонов с помощью коэффициента Жаккара

Table 2. Comparison of plant communities of forest-to-bog ecotones using Jaccard index

\begin{tabular}{|l|c|c|c|}
\hline & For-Efor & Efor-Emire & Emire-Bog \\
\hline Васюганская равнина & 0,45 & 0,43 & 0,36 \\
Чулымская равнина & 0,67 & 0,62 & 0,39 \\
\hline
\end{tabular}

Примечание. Обозначения как на рис. 2.

Помимо повышенного богатства видами, березняки осоково-вейниковые (Efor) характеризуются и специфичностью флористического состава. С одной стороны, они заметно отличаются как от лесов автоморфных местообитаний, так и от сосново-березовых лесов следующей стадии гидроморфной трансформации Васюганской равнины (табл. 2), в обоих случаях общих видов меньше половины. В сообществах, слагающих мезотрофную серию заболачивания, смена видов по мере развития болотного процесса не так интенсивна (табл. 2, Чулымская равнина). С другой стороны, невысоко их сходство и с мезотрофными заболоченными фитоценозами (Efor) $\left(\mathrm{K}_{\mathrm{J}}=0,25\right)$; при попарном сравнении лесов следующей стадии гидроморфной трансформации (Emire) оно выше $\left(\mathrm{K}_{\mathrm{J}}=0,36\right)$. Это также указывает на своеобразие флористического состава березняков на ранней стадии гидроморфной трансформации, которое в значительной мере сглаживается в процессе заболачивания (рис. 4).

Анализ экологических и ценотических свойств видов, слагающих гидроморфные фитоценозы Васюганской равнины, показал, 


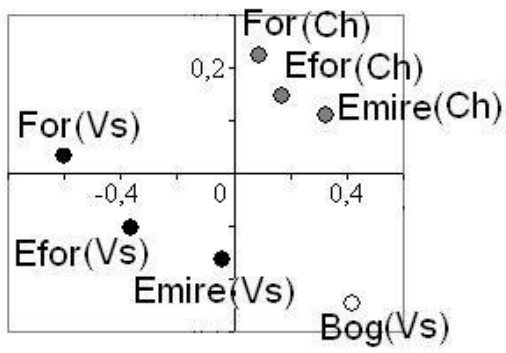

Рис. 4. Взаиморасположение фитоценозов лесоболотных экотонов в абстрактном пространстве NMDS с коэффициентом Жаккара в качестве меры расстояния. Обозначения как на рис. 2

Fig. 4. Interdependence of plant communities of forest-to-bog ecotones in the abstract NMDS space, with Jaccard index as a measure of distance. Notations of plant communities as in Fig. 2

что своеобразие флористического состава березняков осоково-вейниковых во многом определяется повышенной долей лесо- и лугово-болотных видов (трав и мхов), составляющих в них 48 видов и 30 \% обилия и отсутствующих (за исключением 1-2 видов) в заболоченных лесах мезотрофной серии (рис. 5). Большинство этих видов - типичные представители эвтрофных лесных болот (согр), развивающихся в условиях подпитки богатыми грунтовыми водами (порядок Calamagrostio purpureae-Piceetalia obovatae класса Alnetea glutinosae (Лапшина, 2010): травы - Filipendula ulmaria, Carex canescens, C.disperma, C.vaginata, C.cespitosa, мхи Calliergon cordifolium, Climacium dendroides, Plagiomnium ellipticum, Sphagnum squarrosum и др. Эти виды преимущественно требовательны к трофности - мезотрофы, эвмезотрофы, в отличие от мезоолиготрофных видов, слагающих напочвенный покров заболоченных лесов Чулымской равнины.

В сосново-березовых лесах (Emire) доля лесо- и лугово-болотных видов меньше и по составу, и по обилию. Основу напочвенного покрова составляют болотные олиготрофы (Ledum palustre, Chamaedaphne calyculata, Sphagnum angustifolium). Наряду с ними постоянно встречаются мезоолиготрофы (Carex globularis, Sphagnum russowii), проективное покрытие и встречаемость которых в прилегающем болоте ниже. Близкое соотношение видов наблюдается в заболоченных лесах мезотрофной серии (рис. 5) и, согласно утверждению Е.Д. Лапшиной (2010), характерно для сообществ периферии верховых болот, переходных от заболоченных сосняков класса Vaccinio-Piceetea к сообществам типичных верховых болот класса Oxycocco-Sphagnetea.

Выявленные особенности флористического состава березняков Васюганской равнины хорошо согласуются с фитоиндикационной оценкой экотопов, физико-химическими свойствами почв. В сравнении с фитоценозами мезотрофной серии местообитания заболоченных березняков вейниковых при близких значениях увлажнения отличаются по трофности (различия значимые, $\mathrm{p}=0,05$ ) (рис. 6) - почвы в них в среднем на 0,9 ступеней богаче. В лесах более поздней стадии развития заболачивания (Emire) различия меньше (0,4 ступени).

Богатство почв осоково-вейниковых березняков связано с высокой карбонатностью почвообразующих пород, высокой гумусированностью профиля и устойчивым увлажнением почв (рис. 7). Так, фоновыми являются дерновые, в различной степени оподзоленные почвы с признаками более высокой реликтовой гумусированности [Ay-(Ael)-Ah-AB- 

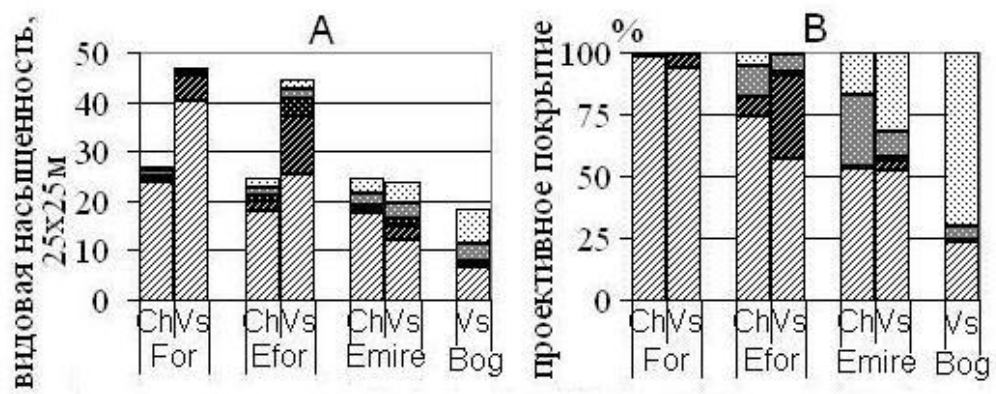

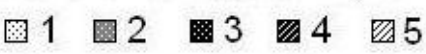

Рис. 5. Ценотические спектры фитоценозов лесоболотных экотонов по видовой насыщенности (А) и по проективному покрытию (В). Обозначения как на рис. 2. Ценотические группы видов: 1 - болотные (олиготрофы); 2 - болотные (мезоолиготрофы); 3 - болотные (мезотрофы); 4 - лесо- и лугово-болотные (мезотрофы и мезоэвтрофы), 5 - лесные (мезотрофы)

Fig. 5. Structural spectra of plant communities of forest-to-bog ecotones in accordance with species number per plot 25x25m (A) and with species cover (B). Notations of plant communities are as in Fig. 2. Groups of species: 1 - bog (oligotrophic); 2 - bog (mesooligotrophic); 3 - mire (mesotrophic); 4 - forest- and meadowswamp (mesotrophic and mesoeutrophic); 5 - forest (mesotrophic)
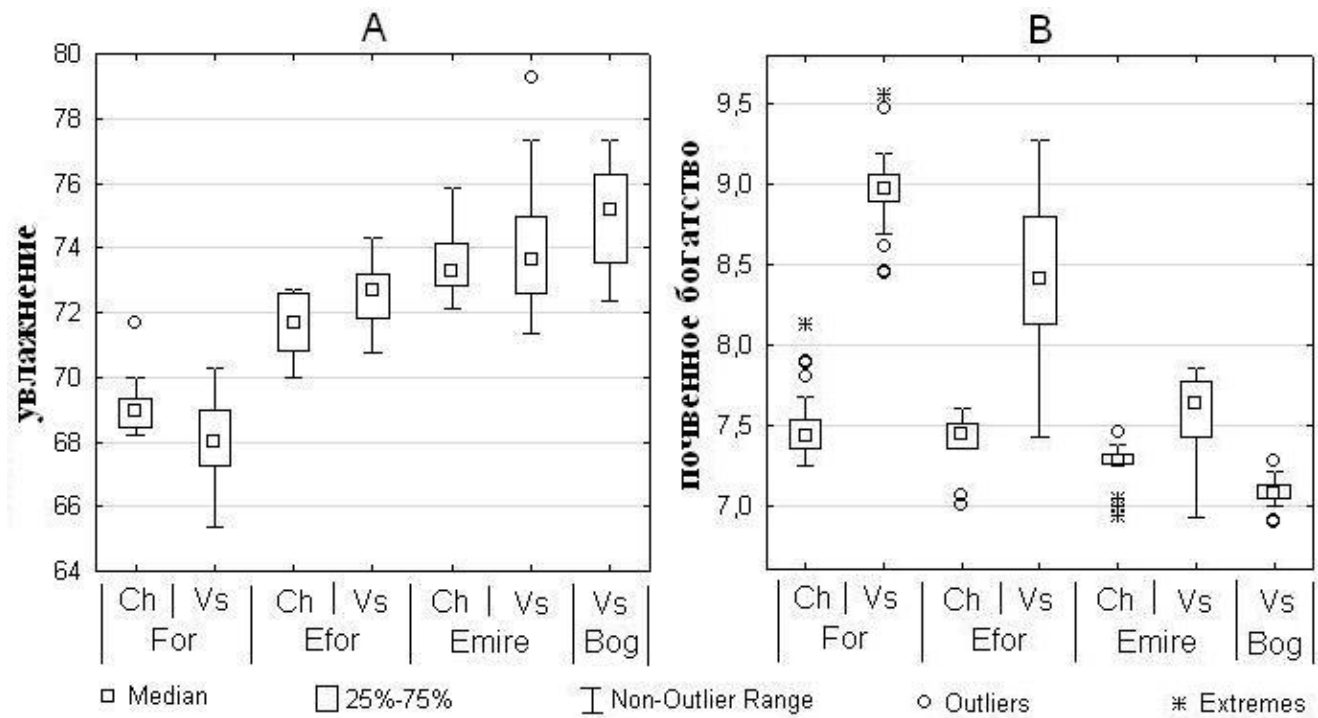

Рис. 6. Фитоиндикационная оценка экотопов в лесоболотных экотонах по фактору увлажнения (А), почвенного богатства (B). Обозначения как на рис. 2. Различия между средними значениями статусов фитоценозов, оцененные критерием Манн-Уитни, значимы $(\mathrm{p}<0.05)$ во всех случаях кроме двух: 1) по фактору увлажнения “Emire(Vs) - Emire(Ch)” p=0,80; 2) по фактору почвенного богатства "For(Ch) Efor(Ch)” p=0,56, что, вероятно, связано с недостаточным числом описаний для Efor(Ch)

Fig. 6. Evaluation of ecotopes in forest-to-bog ecotones with indicator values of plants by the factor of wetness (A) and nutrient availability (B). Notations of plant communities are as in Fig. 2. The differences between the mean values of the status of plant communities, estimated by the Mann-Whitney criterion, are significant $(p<0.05)$ in all cases except for two: 1) by the factor of wetness "Emire(Vs) - Emire(Ch)" $p=0.80$; 2) by the factor of nutrient availability "For(Ch) - Efor(Ch)" $\mathrm{p}=0.56$, which is probably due to the insufficient number of vegetation releves for $\operatorname{Efor}(\mathrm{Ch})$ 


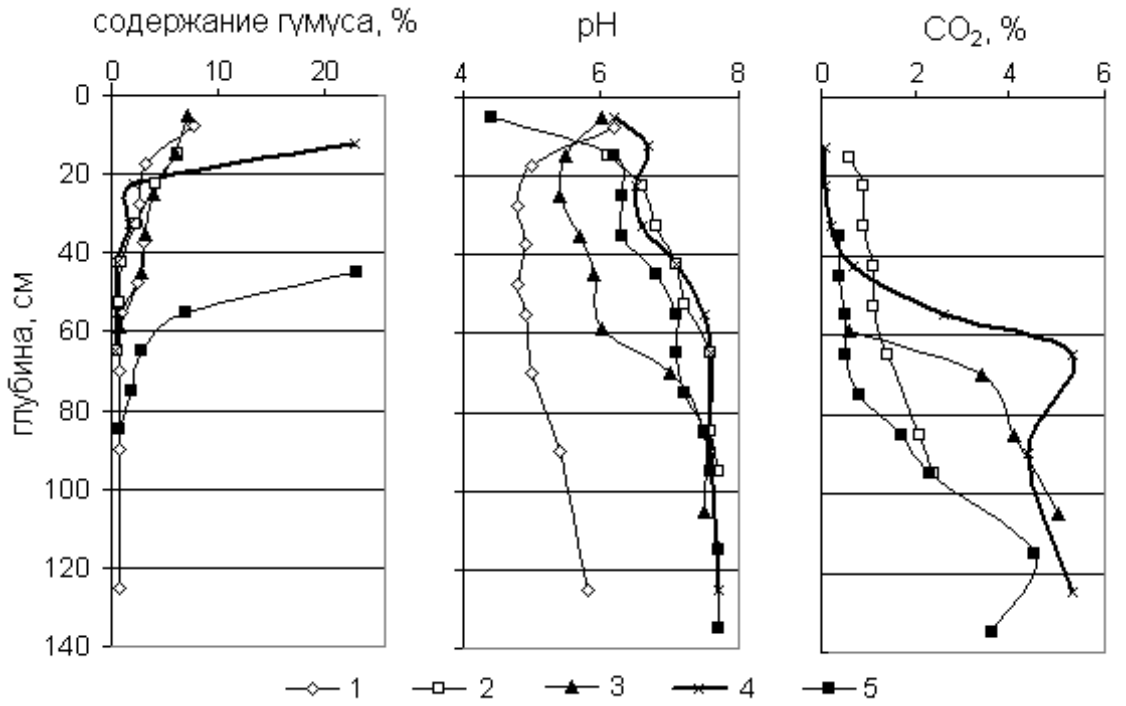

Рис. 7. Химические свойства почв в лесоболотных экотонах Васюганской равнины. $\mathrm{CO}_{2}-$ содержание карбонатов. Почвы: 1 - органо-аккумулятивная дерновая оподзоленная (лес, наиболее дренированная часть трансекта (For), разрез 334); 2 - органо-аккумулятивная дерновая (лес (For), разрез 294); 3 - органоаккумулятивная темно-гумусовая высоковскипающая (лесная часть экотона (Efor) на границе с лесом (For), разрез 386); 4 - органо-аккумулятивная перегнойно-темно-гумусовая (лесная часть экотона (Efor) на границе с болотной частью экотона (Emire), разрез 339); 5 - торфяно-перегнойно-глеевая (болотная часть экотона (Emire), разрез 351)

Fig. 7. Chemical properties of soils in forest-to-bog ecotones on Vasyugan plain. $\mathrm{CO}_{2}-$ carbonate content. Soils: 1 - podzolized organo-accumulative soddy (upland forest (For), the most drained site, pedon 334); 2 - organoaccumulative soddy (upland forest (For), pedon 294); 3 - organo-accumulative dark-humus (forest part of ecotone (Efor) on the border with upland forest (For), pedon 386); 4 - organo-accumulative mucky-dark-humus (forest part of ecotone (Efor) on the border with mire part of it (Emire), pedon 339); 5 - peaty-mucky-gley (mire part of ecotone (Emire), pedon 351)

В-ВСса-Сса]. Мощность гумусовой толщи (включая Ah) 40-50 см. Содержание гумуса как в современном, так и в реликтовом горизонтах составляет 2,5-3,5 \%. Карбонаты в виде сплошной пропитки обнаруживаются с глубины 90-100 см. Органо-аккумулятивные темно-гумусовые почвы [Au-Ah-AB-BcaBCca-Cca] формируются на следующей ступени усиления гидроморфизма и при сравнимой мощности гумусовой толщи отличаются от дерновых более интенсивной прокраской гумусового горизонта, более высоким (до 7 \% в современной и 3-4 \% в реликтовой части) содержанием гумуса. Карбонаты часто встречаются уже с глубины 50-60 см. С развитием гидроморфизма на поверхности почв форми- руется перегнойный горизонт мощностью до 20 см, под которым длительное время сохраняется темно-гумусовый. Содержание гумуса несколько снижается (рис. 7). Карбонаты в приболотной части встречаются уже в нижней части гумусового горизонта или сразу под ним. С ростом болота на поверхности перегнойного формируются различной мощности торфяные горизонты. Все почвы характеризуются высокой насыщенностью основаниями, что определяется карбонатностью пород. Поэтому в составе поглощенных оснований преобладает Са. Практически повсеместно отмечается присутствие в почвенном поглощающем комплексе органо-аккумулятивных почв одновалентных катионов $\mathrm{Na}$ и К. Co- 
держание их невелико и редко превышает $4 \%$ от суммы оснований. По этому признаку К.А. Уфимцева (1974) отнесла большую группу почв южной тайги Западной Сибири к остаточно осолоделым. Присутствие $\mathrm{Na}$ и $\mathrm{K}$ в почвенном поглощающем комплексе указывает на засоленность пород, что является сдерживающим фактором развития лесной растительности.

Почвы березняков осоково-вейниковых в значительной степени отличаются от «зональных» подзолистых и подзолисто-глеевых почв мезотрофной серии с характерными для них грубогумусной подстилкой, невысоким содержанием гумуса (3-5 \%), кислой реакцией ( $\mathrm{pH}$ водный 4,0-4,5), значительной ненасыщенностью основаниями, достигающей 80 \% (Караваева, 1982; Федорчук и др., 2005), и оказываются ближе к заболоченным мезоэвтрофным березнякам (Efremova et al., 2010), хорошо разложившиеся подстилки которых имеют высокую зольность (14-16 \%), насыщенность основаниями (53-55 \%) на фоне слабокислой реакции среды (рН водный 5,0) и сравнительно невысокую гидролитическую кислотность. С повышенным почвенным богатством, вероятно, связано и отмеченное выше сходство флористического состава заболоченных лесов Васюганской равнины с эвтрофными лесными болотами более южных территорий. Хотя осоково-вейниковые березняки и уступают им по этому показателю; по материалам О.Ю. Писаренко с соавт. (Pisarenko et al., 2011), статус богатства почв темнохвойных согр по экологическим шкалам (Методические ..., 1978) 10,5.

Рассмотренные особенности экотопов ранних этапов гидроморфной трансформации на Васюганской равнине во многом определяются составом почвообразующих пород. Низкая водопроницаемость глин обусловливает повышенную увлажненность почв, а карбо- натность сдерживает развитие глеевых процессов и определяет повышенную трофность местобитаний (Dyukarev, Pologova, 2011). Существенное влияние оказывает и береза в качестве лесообразующего вида, «улучшая» лесорастительные условия, по сравнению с темнохвойными, что связано с осветлением, большей прогреваемостью экотопов, большей биомассой богатого кальцием лесного опада и накоплением «мягкого» гумуса (Дюкарев, 2005).

В сосново-березовых лесах, соответствующих следующей стадии гидроморфной трансформации, вследствие ухудшения условий для разложения и минерализации растительных остатков, вызванного изменением гидрологического режима в сторону большей обводненности, на поверхности перегнойного горизонта начинает формироваться торф. Формирование торфяного горизонта приводит к повышению кислотности и снижению богатства почв, закономерной перестройке экологической структуры фитоценозов в сторону преобладания мало требовательных к трофности видов и в конечном итоге обусловливает переходный тип торфонакопления с отложением осоково-древесного торфа. Это сближает сосново-березовые кустарничковомоховые сообщества Васюганской равнины с кустарничково-осоково-сфагновыми лесами мезотрофной серии, развитыми на бескарбонатных суглинках Чулымской равнины (Горожанкина, Константинов, 1976; Пологова и др., 2013), где также отлагается переходный кустарничково-сфагново-древесный торф.

Отмеченное выше увеличение видового богатства в заболоченных березняках Васюганской равнины, по нашему мнению, также связано с повышенным богатством почв. Прямая зависимость между числом видов и трофностью экотопов болотных лесов отмечалась и ранее (Кутенков, Кузнецов, 2013). 


\section{Заключение}

Особенности заболачивания березовых лесов на юге Васюганской равнины тесно связаны с исходной повышенной трофностью местообитаний, определяемой биогеохимическим фоном - карбонатностью почвообразующих пород и богатством почв, что в условиях подпитки грунтово-болотными водами с прилегающих болотных массивов приводит и к замене темнохвойных лесообразующих видов на березу. Это обусловливает более значительную перестройку сообществ в процессе их гидроморфной трансформации по сравнению с типичным мезотрофным заболачиванием темнохвойных таежных лесов на суглинках.

На ранней стадии развития процесса на органо-аккумулятивных темно-гумусовых и перегнойно-темно-гумусовых почвах формируются заболоченные осиновоберезовые леса с доминированием вейника Calamagrostis phragmitoides и участием осок (Carex canescens, C. vaginata, C. disperma). В соответствии с богатством почв элемен- тами минерального питания они характеризуются высоким флористическим разнообразием, сравнимым с разнообразием автоморфных сообществ. Значительную часть напочвенного покрова этих лесов составляют требовательные к трофности лесо- и лугово-болотные виды, характерные для эвтрофных лесных болот (согр) с питанием грунтовыми водами, отсутствующие при мезотрофном заболачивании таежных лесов.

На более поздней стадии гидроморфной трансформации на торфяноперегнойно-глеевых и торфяно-глеевых почвах формируются сосново-березовые кустарничково-моховые леса. На фоне снижения трофности почв уменьшается число слагающих фитоценозы видов, среди них начинают преобладать менее требовательные к почвенному богатству. Это ведет к перестройке экологической структуры сообществ и сближает их с заболоченными лесами мезотрофной серии. Торфонакопление начинается с отложения переходного торфа.

\section{Список литературы / References}

Васильев С.В., Перегон А.М. (2003) Среднемасштабное ландшафтное картографирование болотных и заболоченных территорий (на примере Васюганского болотного комплекса). Вестник Томского государственного университета. Приложение № 7 - Комплексные экологические исследования ландшафтов Сибири. Томск, с. 38-48 [Vasilyev S.V., Peregon A.M. (2003) Medium-scale landscape mapping of wetlands (a case study of Vasyugan swamp complex). Tomsk State University Journal. Annex 7-Integrated ecological studies of the Siberian landscapes. Tomsk, p. 38-48 (in Russian)]

Глебов Ф.З., Ускова Л.М. (1984) Пространственные взаимоотношения леса и болота в таежной зоне Западно-Сибирской равнины. Ботанический журнал, 12: 1634-1640 [Glebov F.Z., Uskova L.M. (1984) Spatial relationships of forest and mire in the taiga zone of the West-Siberia plain. Botanical Journal [Botanicheskiy zhurnal], 12: 1634-1640 (in Russian)]

Горожанкина С.М., Константинов В.Д. (1976) Заболоченные темнохвойные леса среднего Приобья. Теория и практика лесного болотоведения и гидролесомелиорации. Красноярск, c. 19-36 [Gorozhankina S.M., Konstantinov V.D. (1976) Swampy coniferous forests of the middle $\mathrm{Ob}$ region. Theory and practice of forest swamp studies and hydroforestmelioration. Krasnoyarsk, p. 19-36 (in Russian)] 
Горожанкина С.М., Константинов В.Д. (1978) География тайги Западной Сибири. Новосибирск, Наука, 191 с. [Gorozhankina S.M., Konstantinov V.D. (1978) Geography of taiga in Western Siberia. Novosibirsk, Nauka, 191 p. (in Russian)]

Данченко А.М., Бех И.А. (2010) Кедровые леса Западной Сибири. Томск, Томский государственный университет, 424 с. [Danchenko A.M., Bekh I.A. (2010) Pinus sibirica forests of West Siberia. Tomsk, Tomsk State University, 424 p. (in Russian)]

Дюкарев А.Г. (2005) Ландшафтно-динамические аспекты таежного почвообразования в Западной Сибири. Томск, Изд-во НТЛ, 284 с. [Dyukarev A.G. (2005) Landscape-dynamical aspects of soil formation in the taiga of West Siberia. Tomsk, Scientific and technical literature, 284 p. (in Russian)]

Ефремов С.П., Ефремова Т.Т., Назимова Д.И., Кошкарова В.Л., Пименов А.В., Седельникова Т.С., Андреева Н.М., Царегородцев В.Г. (2012) Динамика лесных и болотных экосистем юга Сибири. Разнообразие и динамика лесных экосистем России. Книга 1. Исаев А.С. (ред.) М., Товарищество научных изданий КМК, с. 173-226 [Efremov S.P., Efremova T.T., Nazimova D.I., Koshkarova V.L., Pimenov A.V., Sedelnikova T.S., Andreeva N.M., Tsaregorodtsev V.G. (2012) Dynamics of south Siberia forest and bog ecosystems. Diversity and dynamics of forest ecosystems in Russia. Book 1. Isaev A.S. (ed.) Moscow, KMK, p. 173-226 (in Russian)]

Зверев А.А., Бабешина Л.Г. (2009) Оценка условий местообитаний сфагновых мхов ЗападноСибирской равнины по ведущим экологическим факторам: объекты, материалы и методические основы. Вестник Томского государственного университета, 325: 167-173 [Zverev A.A., Babeshina L.G. (2009) The estimate of the conditions of habitats of Sphagnum mosses in West Siberian plain by the key environmental factors: objects, data and methodical basis. Tomsk State University Journal [Vestnik Tomskogo gosudarstvennogo universiteta], 325: 167-173 (in Russian)]

Игнатов М.С., Афонина О.М. (1992) Список мхов территории бывшего CСCР. Arctoa, 1: 1-85 [Ignatov M.S., Afonina O.M. (1992) Check-list of mosses of the former USSR. Arctoa, 1: 1-85 (in Russian)]

Караваева Н.А. (1982) Заболачивание и эволюция почв. М., Наука, 296 с. [Karavaeva N.A. (1982) Bogging and the evolution of soils. Moscow, Nauka, 296 p. (in Russian)]

Конспект флоры Сибири: Сосудистые растения (2005) Новосибирск, Наука, 362 с. [A list of flora in Siberia: Vascular plants (2005) Novosibirsk, Nauka, 362 p. (in Russian)]

Кутенков С.А., Кузнецов О.Л. (2013) Разнообразие и динамика заболоченных и болотных лесов европейского севера России. Разнообразие и динамика лесных экосистем России. Книга 2. Исаев А.С. (ред.) М., Товарищество научных изданий КМК, с. 152-204 [Kutenkov S.A., Kuznetsov O.L. (2013) Diversity and dynamics of forested mires and paludified forests on the European North of Russia. Diversity and dynamics of forest ecosystems in Russia. Book 2. Isaev A.S. (ed.) Moscow, KMK, p. 152-204 (in Russian)]

Лапшина Е.Д. (2003) Флора болот юго-востока Западной Сибири. Томск, Изд-во Том. унта, 296 c. [Lapshina E.D. (2003) Flora of the marshes of the South-East of West Siberia. Tomsk, Tomsk State University, 296 p. (in Russian)]

Лапшина Е.Д. (2010) Растительность болот юго-востока Западной Сибири. Новосибирск, 186 c. [Lapshina E.D. (2010) The vegetation of wetlands of the South-East of West Siberia. Novosibirsk, 186 p. (in Russian)] 
Лапшина Е.Д., Пологова Н.Н., Мульдияров Е.Я. (2000) Болота водораздельных равнин юга лесной зоны Западной Сибири. Krylovia, 2(1): 38-43 [Lapshina E.D., Pologova N.N., Mouldiyarov E.Ya. (2000) The watershed plain wetlands in south of forest zone of West Siberia. Krylovia, 2(1): 38-43 (in Russian)]

Лащинский Н.Н. (2009) Растительность Салаирского кряжа. Новосибирск, Гео, 263 с. [Lashchinskyi N.N. (2009) Vegetation of the Salair ridge. Novosibirsk, Geo, 263 p. (in Russian)]

Лащинский Н.Н., Королюк А.Ю. (2015) Синтаксономия темнохвойных зональных лесов южной тайги Западно-Сибирской равнины и гумидных низкогорий Алтае-Саянской горной области. Растительность России, 26: 85-107 [Lashchinsky N.N., Korolyuk A.Yu. (2015) Syntaxonomy of zonal dark-coniferous forests of southern taiga of the West Siberian plain and of humid low-mountains of the Altai-Sayan mounain region. Vegetation of Russia [Rastitel'nost' Rossii], 26: 85-107 (in Russian)]

Методические указания по экологической оценке кормовых угодий тундровой и лесной зон Сибири и Дальнего Востока по растительному покрову (1978) М., 302 с. [Guidelines for ecological assessment of forage lands of the tundra and forest zones of Siberia and the Far East based on vegetation cover (1978) Moscow, 302 p. (in Russian)]

Пологова Н.Н. (2001) Лесоболотные экотоны в болотообразовательном процессе. Сибирский экологический журнал, 8(6): 675-681 [Pologova N.N. (2001) Forest-swamp ecotones in the swamp formation process. Siberian Journal of Ecology [Sibirskiy ekologicheskiy zhurnal], 8(6): 675681 (in Russian)]

Пологова Н.Н., Дюкарев А.Г. (2012) Структура и динамика лесоболотных экотонов. Исследование природно-климатических прочессов на территории Большого Васюганского болота. Кабанов М.В. (ред.) Новосибирск, Изд-во СО РАН, с. 214-230 [Pologova N.N., Dyukarev A.G. (2012) Structure and dynamics of forest-bog ecotones. Research of natural and climatic processes on the Great Vasyugan mire. Kabanov M.V. (ed.) Novosibirsk, Siberian Branch of the Russian Academy of Sciences, p. 214-230 (in Russian)]

Пологова Н.Н., Чернова Н.А., Климова Н.В., Дюкарев А.Г. (2013) Разнообразие кедровых лесов в связи с условиями местообитаний. Лесоведение, 4: 32-42 [Pologova N.N., Chernova N.A., Klimova N.W., Dyukarev A.G. (2013) Diversity of siberian pine forests related to their habitat. Forestry studies [Lesovedenie], 4: 32-42 (in Russian)]

Природно-ресурсное районирование Томской области (1997) Томск, Спектр, 40 с. [Natural resource zoning of Tomsk region (1997) Tomsk, Spectr, 40 p. (in Russian)]

Пьявченко Н.И. (1985) Торфяные болота, их природное и хозяйственное значение. М., Наука, 152 с. [P'yavchenko N.I. (1985) Peat bogs, their natural and economic value. Moscow, Nauka, 152 p. (in Russian)]

Ружанский В.В. (1972) Гидрогеологические условия. Природные условия освоения междуречья Обь-Иртылш. Жуков В.М., Занин Г.В., Нейштадт М.И. (ред.) М., с. 32-36 [Ruzhanskii V.V. (1972) Hydrogeological conditions. Natural conditions of development of the Ob-Irtysh interfluve. Zhukov V.M., Zanin G.V., Neistadt M.I. (eds.) Moscow, p. 32-36 (in Russian)]

Смирнов В.Э., Ханина Л.Г., Бобровский М.В. (2014) Оценка видового разнообразия растительности на основе интегрального статистического подхода в условиях неоднородных данных (на примере заповедника «Калужские засеки»). Вестник Томского государственного универси- 
тета. Биология, 4(28): 70-87 [Smirnov V.E., Khanina L.G., Bobrovsky M.V. (2014) Assessment of vegetation species diversity based on the integrated statistical approach for heterogeneous data (a case study for the "Kaluzhskie zaseki” State Nature Reserve). Tomsk State University Journal of Biology [Vestnik Tomskogo gosudarstvennogo universiteta. Biologiya], 4(28): 70-87 (in Russian)]

Уфимцева К.А. (1974) Почвы южной части таежной зоны Западно-Сибирской равнины. М., Колос, 206 с. [Ufimtseva K.A. (1974) Soils of the southern part of the taiga zone of the West Siberian Plain. Moscow, Kolos, 206 p. (in Russian)]

Федорчук В.Н., Нешатаев В.Ю., Кузнецова М.Л.(2005) Лесные экосистемы северо-западных районов России: Типология, динамика, хозяйственные особенности. СПб., 382 c. [Fedorchuk V.N., Neshatayev V.Yu., Kuznetsova M.L. (2005) Forest ecosystems of the North-Western regions of Russia: Typology, dynamics, forest management features. St-Petersburg, 382 p. (in Russian)]

Храмов А.А., Валуцкий В.И. (1977) Лесные и болотные фитоценозы Восточного Васюганья. Новосибирск, Наука, 222 с. [Khramov A.A., Valutskii V.I. (1977) Forest and swamp plant communities of the Eastern Vasyugan land. Novosibirsk, Nauka, 222 p. (in Russian)]

Bohn T.J., Melton J.R., Ito A., Kleinen T., Spahni R., Stocker B.D., Zhang B., Zhu X., Schroeder R., Glagolev M.V., Maksyutov S.S., Brovkin V., Chen G., Denisov S.N., Eliseev A.V., GallegoSala A., McDonald K.C., Rawlins M.A., Riley W.J., Subin Z.M., Tian H., Zhuang Q., Kaplan J.O. (2015) WETCHIMP-WSL: intercomparison of wetland methane emissions models over West Siberia. Boigeosciences, 12(11): 3321-3349

Colwell R.K. Estimates: statistical estimation of species richness and shared species from samples. Version 9.2013. User's Guide and application published at: http://purl.oclc.org/estimates.

Dyukarev A.G., Pologova N.N. (2011) Soils with complex organic profiles on the Vasyugan Plain. Eurasian Soil Science, 44(5): 480-492

Efremova T.T., Efremov S.P., Avrova A.F. (2010) Correlation between the morphogenetic types of litter and their properties in bog birch forests. Eurasian Soil Science, 43(8): 858-866

Magurran A.E. (2004) Measuring biological diversity. Blackwell Publishing, 256 p.

Paradis E., Rochefort L., Langlois M. (2015) The lagg ecotone: an integrative part of bog ecosystems in North America. Plant Ecology, 216(7): 999-1018

Pisarenko O.Y., Lapshina E.D., Mul'diyarov E.Y. (2011) Cenotic positions and ecological amplitudes of mosses in the vegetation of the Great Vasyugan Swamp. Contemporary Problems of Ecology, 4(3): 283-295

Ratcliffe J.L., Creevy A., Andersen R., Zarov E., Gaffney P.P.J., Taggart M.A., Mazei Y., Tsyganov A.N., Rowson J.G., Lapshina E.D., Payne R.J. (2017) Ecological and environmental transition across the forested-to-open bog ecotone in a west siberian peatland. Science of the Total Environment, 607-608: 816-828 